\author{
ANNA Fiń \\ Alla Karnaukh-Brożyna \\ Uniwersytet Pedagogiczny w Krakowie
}

\title{
MARKA JAKO OBRAZ
}

\section{Wprowadzenie}

Prezentowany artykuł podejmuje próbę opisu marki: lokalnej, regionalnej, narodowej w kategoriach obrazu. Na polu nauki istnieje dość bogata literatura poświęcona pojęciom marki i obrazu. Nie ma jednak opracowań, które w jakiś sposób łączyłyby ze sobą te dwie kategorie pojęciowe. Główną osią konstrukcji tego artykuły jest traktowanie „obrazu” jako ważnej ramy interpretacyjnej dla pojmowania marki. Ustalenia nauk o zarządzaniu i marketingu, desygnujące zwykle markę jako znak firmowy (fabryczny) i/lub wizerunek są przez nas celowo pominięte. W ten sposób próbujemy nieco odejść od tradycji myślenia o marce - zwłaszcza lokalnej i narodowej - i otworzyć niejako nowe możliwości jej interpretacji i poznania. Inspiracji do przyjęcia takiego sposobu konceptualizowania marki dostarczyła nam, klasyczna już dziś praca Waltera Lippmanna Public Opinion, która wydana została w 1922 roku. W jednym z rozdziałów swojej słynnej książki W. Lippmann pisze o "obrazach w naszych głowach” (the pictures in our heads) i odnosi je do utrwalonych w świadomości społecznej wyobrażeń/ symbolicznych reprezentacji o ludziach, miejscach, krajach, obiektach, nas samych [Lippman 1998: 3-32]. Prezentując subiektywistyczną wizję społeczeństwa i zachowania człowieka, formułuje on pogląd, wedle którego ludzie mają tendencję do personifikowania zjawisk: „nie potrafimy żywić wielkiego zainteresowania czy też wzruszać się rzeczami, których nie widzimy. Każdy z nas widzi tylko niewiele spraw publicznych i dlatego pozostają one nudne i nieatrakcyjne, dopóki ktoś o zdolnościach artystycznych nie przetłumaczył ich na język filmu" [cyt. za: Gostkowski 1959: 62]. I chociaż przedstawiona przez Lippmanna linia argumentacji stworzyła podwaliny pod rozwój teorii stereotypu, a same „obrazy w ludzkich głowach” traktowane są jako semantyczny równoważnik znaczenia nadawanego 
nazwie stereotyp [Kubiak 1993: 26], to równie dobrze odnieść je możemy do innych zjawisk z dziedziny świadomości społecznej, do pewnych, utrwalonych wyobrażeń - obrazów myślowych ${ }^{1}$. Te obrazy to nic innego jak pewne, określone wizje, sposoby postrzegania: miejsc, postaci, wydarzeń. Są one konstruowane przez ludzi w określonych warunkach społecznych i historycznych i jak pisze Lippmann „przeżywają te warunki i kontynuują swe istnienie (...) traktowane dalej z nabożną czcią jako coś w rodzaju tabu czy fetysza" [Gostkowski 1959: 52]. Tak też traktować można markę lokalną i narodową - jako swego rodzaju obraz myślowy, jako coś wyobrażonego, alegoryczny obraz miasta, kraju, produktu; stworzony przez ludzi (aktorów społecznych), podzielany, rozpoznawany i trwały. Marka, a właściwie marka-obraz, istnieje w myślach i dzięki temu staje się ona rzeczywista. Bo jak wiele dekad po Lippmannie i w zasadzie niejako w „oderwaniu” od jego koncepcji, napisał Piotr Sztompka „percepcja świata zewnętrznego zostaje coraz bardziej upośredniona przez obrazy” [Sztompka 2012: 13]. W artykule tym będziemy szli tą teoretyczną drogą i będziemy starali się odtworzyć markę jako swego rodzaju wizualną konstrukcję, jako wspomniany, tytułowy obraz.

Empiryczny kontekst dla prowadzonych rozważań stanowią badania przeprowadzone w ramach projektu Odświętne tworzenie i propagowanie marek (narodowej, lokalnej, regionalnej) w społecznościach lokalnych, którego celem była diagnoza oddolnego i odświętnego mechanizmu tworzenia marki lokalnej i narodowej. Analizie poddane zostały festyny i święta lokalne w czterech społecznościach lokalnych, zróżnicowanych pod względem lokalizacji geograficznej oraz odmiennych charakterystyk badanego wydarzenia kulturalnego. Były to: (a) Wincentiada - Dni Patrona Miasta Przemyśla; (b) Dożynki Prezydenckie organizowane w Spale; (c) Jarmark Sanocki organizowany w Sanoku oraz (d) Księżackie Jadło Festiwal Dobrej Żywności mający miejsce w Łowiczu. Przedstawione przez nas rozważania są wynikiem przeprowadzonych indywidualnych wywiadów pogłębionych $\mathrm{z}$ organizatorami wymienionych wydarzeń i reprezentantami instytucji kultury; badań ankietowych wśród uczestników wydarzeń oraz poczynionych obserwacji.

Czyni tak zresztą sam Lippmann odnosząc „obrazy w głowach” do opinii publicznej, zob. więcej: [Kubiak 1993: 24-27]. 


\section{Marka jako obraz: teoretyczna próba wyjaśnienia podejścia}

W przyjętej przez nas perspektywie podstawową kategorią pojęciową wymagającą wyjaśnienia jest pojęcie obrazu. Według Słownika Języka Polskiego obraz odnieść można do następujących terminów: dzieła plastycznego, wyobrażenia, wizerunku, widoku na ekranie, filmu, całościowego opisu kogoś lub czegoś [Słownik... 2016]. Jeśli za początek teoretycznych rozważań przyjmiemy platońską krytykę obrazu, to okazuje się, że w dyskursie naukowym problematyka ta pojawiła się już na gruncie starożytnej filozofii. W ramach tej dyscypliny znalazła też swoich kontynuatorów w postaci Ludwiga Feuerbacha, Arthura Schopenchauera, Romana Ingardena czy Martina Heideggera. Ten ostatni, w swoich rozważaniach nad czasem światoobrazu pisał, iż „podstawowym procesem nowożytności jest podbój świata jako obrazu" [Heidegger, 1993: 19] wyprzedzając tym samym, tych wszystkich teoretyków, którzy z końcem lat 60. XX wieku zaczęli pisać o piktorialnym charakterze współczesnej kultury. Szczególnie dużo odniesień na temat definiowania obrazu pojawia się w naukach o sztuce. Maria Rzepińska twierdzi np., że obraz powinien być ujmowany zarówno jako przedmiot estetyczny, jak i obiekt materialny, powstający w określonych warunkach historycznych [Rzepińska 1988: 138-153]. W tym sensie jest on wytworzonym fizycznie przedmiotem, ograniczonym do swojego artystycznego charakteru, posiadającym walory estetyczne i sensualne. Próby określenia tego czym jest obraz, pojawiły się także na gruncie nauk społecznych. Rozkwit badań nad problematyką obrazu w naukach społecznych przypada na drugą połowę XX wieku, kiedy to badacze dostrzegać zaczęli ważnośći dominację w społeczeństwie tzw. kultury wizualnej, która zdaniem Nicholasa Mirzoeffa „nie opiera się na samych obrazach, lecz na nowoczesnej skłonności do obrazowania lub wizualizowania egzystencji” [Mirzoeff 2012: 163]. Czyniąc obrazy przedmiotem swoich analiz badacze społeczni zaczęli je konceptualizować po pierwsze, przez pryzmat środka umożliwiającego poznanie życia społecznego ${ }^{2}$; po drugie, przez pryzmat funkcji, jakie pełnią one w społeczeństwie: artystycznej (ekspresyjnej i estetycznej), informacyjnej, komercyjnej, perswazyjnej i propagandowej [Sztompka 2012: 15] oraz komunikacyjnej ${ }^{3}$. Jednocześnie zaczęto odchodzić od opisywania

Piotr Sztompka pisze np., że obraz, „stanowi nie tylko samoistny obiekt poznania, ale też środek poznania czegoś więcej, mianowicie życia społecznego", zob. [Sztompka 2012: 8].

3 Na taką rolę obrazu zwraca przede wszystkim, nawiązując do koncepcji Sola Wortha obrazu jako aktu komunikacyjnego, zob. [Olechnicki 2003: 58-59]. 
obrazu tylko jako obiektu materialnego (fizycznego), mającego zapewnić doznania wizualne/zmysłowe. Obrazy przestały być utożsamiane tylko z ikonosferą zawężoną do obrazów wzrokowych [Olechnicki, 2003: 9], a ich pole semantyczne zostało poszerzone o myśl, stan percepcji, o te rzeczy, które, jak zauważa Krzysztof Olechnicki, same przez się wizualnymi nie są ${ }^{4}$. Najpełniej pisał o tym Hans Belting, twierdząc iż „żyjemy obrazami i rozumiemy świat w obrazach" [Belting 2012: 8] W swoich rozważaniach poświęconych antropologii obrazu $\mathrm{H}$. Belting akcentuje przede wszystkim symboliczne znaczenie obrazów i przez to proponuje utożsamić je zarówno z obszarem wizualnym, jak i ze znakiem ikonicznym [Belting 2012: 11-14]. Dokonuje jednocześnie delimitacji obrazów na zewnętrzne (dostrzegalne za pośrednictwem różnych rozwiązań technicznych, np. obraz fotograficzny) oraz wewnętrzne (endogeniczne, należące do ciała, można powiedzieć inaczej: istniejące w wyobraźni, utrwalone w świadomości), [Belting 2012: 26-30]. Ciekawe jest przy tym to, że wszystkie teoretyczne dyskusje na temat obrazu, wykraczające niejako poza estetyczną sferę obrazu i „dostrzegalny” obszar wizualny/jego wymiar wzrokowy, toczyły się niejako bez uwzględnienia lippmannowskiej koncepcji „obrazów w ludzkich głowach”. A przecież do tego właśnie wymiaru odnieść możemy owe obrazy wewnętrzne czy wspomnianą ludzką skłonność do obrazowania i wizualizowania rzeczywistości społecznej i otaczającego świata.

Posługując się takim zapleczem teoretycznym traktujemy markę właśnie jako obraz. Marka-obraz jest konstruktem funkcjonującym w świadomości jednostek, obecnym i utrwalonym w zbiorowej pamięci i jako taka ma siłę oddziaływania i spotyka się z publicznym odbiorem. Jest też konstruktem, który ma swój wymiar materialny, może być bowiem zwizualizowana i przedstawiona graficznie. Jest zatem i znakiem ikonicznym i obszarem wizualnym; obrazem wewnętrznym, tym w „ludzkiej głowie”, jak i obrazem zewnętrznym, wytworzonym fizycznie, mającym wymiar wizualny. Fundamentalne znaczenie ma tu fakt, że produkcja marki-obrazu podlega społecznemu procesowi ${ }^{5}$. Marka-obraz jest tworzona przez ludzi - jest zatem wytworem aktywności człowieka, odnosi się do określonego elementu życia społecznego/pewnego wymiaru rzeczywistości danej społeczności i jest odbierana przez innych. Takie postawienie problemu prowadzi do spojrzenia

4 Wyrazem tej tendencji są słowa K. Olechnickiego, który napisał iż: „obrazuje się i wizualizuje całą egzystencję ludzką" [Olechnicki 2003: 95].

5 O społecznym wytwarzaniu obrazów pisała m.in. Gillian Rose, uważając, że taki sposób konstrukcji obrazów wymaga w ich analizie użycia wiedzy o procesach kulturowych, społecznych i ekonomicznych zachodzących w danym społeczeństwie, zob. [Rose 2010: 38]. 
na markę lokalną i narodową w kontekście, powstałej w połowie XX wieku, koncepcji konstruktywizmu społecznego. Podejście konstruktywistyczne opiera się na założeniu, że występujące w świecie obiekty nie istnieją niezależnie od podmiotu poznającego, ale są przezeń konstruowane [Wendland 2011: 13-20]. Prekursorzy koncepcji Peter L. Berger oraz Thomas Luckmann, wskazali na trzy zasadnicze procesy, dzięki którym wytworzone elementy społecznej rzeczywistości stają się przedmiotem świadomości człowieka, a następnie świadomości zbiorowej: eksternalizacji, obiektywizacji i internalizacji [Berger, Luckmann 2010]. Dzięki tym procesom, istnienie/ trwałość tego co społecznie wytworzone jest stale podtrzymywane. W konstruktywizmie społecznym zawarta jest teza, że do budowania określonych społecznych obiektów/zjawisk/elementów społecznej rzeczywistości wykorzystywany jest właściwy dla określonej społeczności „społeczny zasób wiedzy" [Berger, Luckmann 2010: 62]. Również tworzywem marki lokalnej i narodowej jest przekazywana w toku komunikacji wiedza. Jest zatem marka-obraz „produktem podmiotu działającego, interpretującego uniwersum na wiele kulturowo określonych sposobów” [Manterys 1997: 54].

\section{Społeczne tworzenie marki-obrazu}

Przeprowadzone przez nas badania pozwalają określić, które podmioty działające biorą udział w społecznym wytwarzaniu marki lokalnej/regionalnej/narodowej, na jakich poziomach odbywa się owo tworzenie oraz na podstawie których elementów (społecznego zasobu wiedzy) dokonuje się akt konstrukcji. Analiza zebranego w trakcie badań materiału empirycznego wskazuje, że kluczowe działania w zakresie kreowania marki lokalnej podejmują dwa zasadnicze podmioty: tzw. aktorzy profesjonalni oraz aktorzy „społeczni”. Pojęcie aktora „społecznego” ma tu charakter opozycyjny do kategorii aktora „profesjonalnego”. W tym kontekście aktorzy „społeczni” to osoby, które uczestniczą w tworzeniu marki lokalnej przede wszystkim dobrowolnie, a więc bez żadnej formalnej, czy służbowej (zawodowej) obligacji do podejmowania takich działań; natomiast aktorzy "profesjonalni” to wyspecjalizowane podmioty zajmujące się tworzeniem i propagowaniem marki: przedstawiciele władz miasta, instytucje kultury, stowarzyszenia społeczno-kulturalne. Wyniki zebrane we wszystkich czterech miejscowościach pokazują, że osoby badane, reprezentujące aktorów „społecznych” w kreowaniu marki postrzegają same siebie i swoją kategorię jako ważną i względnie aktywną kategorię podmiotów tworzących i promujących markę. Jednocześnie uznają oni 
pierwszeństwo w tworzeniu marki profesjonalnych podmiotów: przedstawicieli świata kultury (stowarzyszeń społecznych i kulturalnych i instytucji kultury) oraz lokalnych władz (aneks, wykres 1). To poczucie sprawczości czy swego rodzaju kreacjonistyczne postawy są oczywiście zróżnicowane w poszczególnych, uwzględnionych w badaniu miejscowościach: największe w Przemyślu i Sanoku, mniejsze w Łowiczu i Spale (innymi słowy wyższe w obszarze wielokulturowym niż monokulturowym); nie mniej jednak, uwypuklanie roli podmiotów zbiorowych: stowarzyszeń, instytucji kultury i samych mieszkańców (zwłaszcza tych najbardziej zaangażowanych mieszkańców miasta), świadczy o uspołecznieniu procesu tworzenia i propagowania marki lokalnej. Markę lokalną tworzą zatem

wszyscy którzy działają na rzecz Sanoka, ale instytucje przede wszystkim (...) Wszyscy razem, choć inaczej, w zakresie swoich kompetencji. A ludzie jak mówiłam przed chwilą też są ważni. (SKS4_14)

Analiza zebranych opinii pozwala sformułować stwierdzenie, że społeczne tworzenie marki lokalnej powinno odbywać się przy wykorzystaniu zasobów ludzkich (wspólnym zaangażowaniu) i kapitału społecznego oraz kulturowego społeczności lokalnej, przy jednoczesnej koordynacji tego procesu przez odpowiednie władze:

organizatorem marki może być pani, mogę być ja, tylko to musi być poparte przez władze. Że władze to akceptują. Nie będą przeszkadzały, tylko będą pomagały. Bo to wymaga wsparcia. Bo to każdy może markę wymyślić, tylko co dalej z tym zrobić. (ŁA5)

Analizując działania podmiotów „profesjonalnych” można wyodrębnić dwa zasadnicze modele strategii działań podejmowanych w zakresie kreowania marki lokalnej. Po pierwsze, mówić tu możemy o modelu partycypacyjnym/inkluzyjnym, który opiera się na: uzgadnianiu stanowisk; włączaniu w działania instytucje kultury, środowisko sektora pozarządowego, nieformalnych animatorów kultury i mieszkańców społeczności lokalnych oraz na podziale zadań, tak, że rola głównego organizatora (władz i naczelnych instytucji kultury) sprowadza się głównie do nadzorowania i finansowania działań. Po drugie zaś możemy mówić o modelu dyrektywnym/ ekskluzyjnym, gdzie proces decyzyjny jest scentralizowany, opiera się raczej na jednostronnej komunikacji, gdzie nie uwzględnia się lub uwzględnia w stopniu minimalnym zaangażowanie i pomysły innych instytucji, zwłasz- 
cza stowarzyszeń społeczno-kulturalnych oraz mieszkańców. Na podstawie zebranego materiału empirycznego trudno jest oczywiście oszacować, który z opisanych modeli strategii działań jest efektywniejszy jeśli chodzi o proces kreowania marki. Biorąc pod uwagę zebrane opinie można wysunąć bardzo ostrożną tezę, że obydwa. Wszak nie o ich ewaluację chodzi, a o wskazanie społecznych sposobów kreacji marek-obrazów. Ponieważ „aktywność podmiotu działającego osadzona jest zawsze w otoczeniu społeczno-kulturowym" [Manterys 1997: 45], z punktu widzenia prowadzonej analizy ważniejsze jest określenie z jakich elementów; a konkretnie z jakich „społecznych zasobów wiedzy”, czerpią zarówno aktorzy „społeczni”, jak i „profesjonalni” w procesie wytwarzania marek lokalnych. Badania wykazały, że bez względu na to czy akt kreacji odbywa się w środowisku wielo czy monokulturowym, podstawowymi zasobami wykorzystywanymi w tym procesie są:

a) zasoby kulturowe społeczności lokalnej [postaci (znaczące i rozpoznawalne w społeczności lokalnej i/lub w środowisku zewnętrznym, w tym na arenie międzynarodowej), lokalne tradycje gospodarcze, historyczna przeszłość, dziedzictwo kulturowe, słowem wszystko to do czego można się odnieść i jest blisko związane ze społecznością, świadczy o jej specyfice i wyjątkowości; np. wszelkie odniesienia do dziedzictwa wielokulturowości i galicyjskiej przeszłości ziemi sanockiej czy przemyskiej; często wykorzystanie tego typu zasobów wiąże się z procesem mitologizacji przeszłości];

b) zasoby kulturowo-geograficzne (atrakcyjne położenie geograficzne i związana z tym symbolika np. Bieszczady, Karpaty i związana z nimi symbolika, wykorzystanie potencjału pogranicznego położenia);

c) zasoby ludzkie (sieci interpersonalnych powiązań, obecność pasjonatów, entuzjastów, profesjonalistów, inicjatywy oddolne-żywiołowe);

d) zasoby instytucjonalne (nawiązywanie współpracy międzyinstytucjonalnej zarówno z instytucjami lokalnymi jak i ponad lokalnymi; istnienie strategii rozwoju kulturalnego; polityki kulturalnej);

e) potencjał strukturalny (odpowiednie rozwiązania prawne oraz akcesja do Unii Europejskiej; wykorzystanie potencjału wynikającego $\mathrm{z}$ akcesji Polski do struktur unijnych tkwiącego m.in. w zmianie przepisów prawnych czy lepszych możliwości finansowania podejmowanych działań);

f) zewnętrzne wpływy i inspiracje (ponadlokalne, ale i międzynarodowe np. czerpanie $\mathrm{z}$ rozwiązań przyjętych przez tzw. miasta partnerskie); 
g) zgodność definicji marki czy inaczej: spójna wizja marki (brak zgodności definicji powoduje polaryzację środowiska, w którym można by powiedzieć każdy kreuje „markę”; konsekwencją może być swoista „wielość marek”, przy jednoczesnym braku marki dominującej);

h) aspekt tożsamości (identyfikacja $\mathrm{z}$ miastem oraz wewnętrzne przekonanie podmiotów, że dane wydarzenie/produkt/symbol jest czymś istotnym, wartym utożsamiania się z nim).

Społeczne tworzenie marki lokalnej, regionalnej i narodowej opiera się zatem o szereg czynników o charakterze lokalnym (wewnętrznych) i ponadlokalnym (zewnętrznych). Ważnym aspektem społecznego wytwarzania marki, podobnie jak zresztą obrazu, są tożsamości społeczne:

oczywiście można zacząć budować taką markę od zera. Wymyślić najsubtelniejszy znaczek, no, specjaliści się na tym znają, i zacząć wydawać pieniądze, żeby to utrwalić. Ale jeżeli pominiemy te metody, to najlepiej byłoby, moim zdaniem odcedzić, szukając w tym sicie to, co już jest identyfikowane jako nasze, własne i również identyfikowane przez obcych jako nasz znak wyróżniający. (ŁA4)

Marka-obraz musi najpierw pojawić się w świadomości podmiotów działających, a kiedy zostanie zidentyfikowana rozpoczyna się proces opracowywania strategii związanej z jej promocją, komercjalizacją i w konsekwencji proces utrwalania $\mathrm{w}$ zbiorowej pamięci, a następnie odbioru.

Pogłębiona analiza zasobów wykorzystywanych przy społecznym tworzeniu marki-obrazu pozwala zaobserwować, że podmioty działające konstruują markę z elementów już zastanych bądź też podejmują się kreowania nowych wzorów, które następnie wykorzystywane są do budowania obrazu. Biorąc to pod uwagę, a także wyszczególnione strategie działań, możemy wyróżnić cztery zasadnicze typy marek-obrazów: obrazy „narzucone”; obrazy „długiego trwania”; obrazy „na sprzedaż” oraz obrazy typu „brand mind map". Oczywiście kategorie te nie są całkowicie rozłączne. Nachodzą niekiedy na siebie, co oznacza, że np. obrazy „długiego trwania” mogą być jednocześnie obrazami „na sprzedaż”. Podział ten traktować należy jako umowny. Są to swoiste typy idealne; ukazujące złożoność sposobów patrzenia na markę i jej proces społecznego wytwarzania. Generalnie na obrazy te najczęściej składają się: produkty rzemieślnicze lub kulinarne; współczesne wydarzenia; symbole i postacie. W badanych miejscowościach wyszczególnić można całe spektrum takich elementów; tu zwrócimy uwagę tylko na wybrane. 


\section{Typy marek-obrazów}

\section{Obrazy „narzucone”}

Obrazy „narzucone” odnoszą się do marek wytwarzanych/konstruowanych albo opartych na „tradycji wymyślonej” albo niejako „odtworzonej”. Są one budowane na podstawie treści, których w danej miejscowości nie było lub z którymi nie było silnej identyfikacji (czyli takie, które w przeszłości w zbiorowej pamięci nie były obrazem miejsca). Ważne jest przy tym zaznaczenie faktu, że proces identyfikacji mieszkańców miast z tymi obrazami bywa bardzo zróżnicowany i nie ma tu jednoznacznej zgody co do wizerunkowej jego roli. Najpełniej ten typ marek oddają słowa jednego z rozmówców: ,jak nie ma, to trzeba wymyślać, tak jak Jasło wymyśliło Dni Wina” (SKP2_14).Typowymi przykładami obrazów „narzuconych” są Dożynki Prezydenckie organizowane w Spale, Dni Wina w Jaśle, Karpackie Klimaty w Krośnie, a także Wincentiada - Dni Patrona Miasta Przemyśla. Dożynki Prezydenckie to wydarzenie/święto lokalne, mające charakter narodowy, ogólnopolski, organizowane z udziałem prezydenta i przedstawicieli władz państwowych. W przypadku tego wydarzenia mamy do czynienia $z$ nawiązaniem do tradycji Dożynek organizowanych w Spale w okresie międzywojennym. W nowej formie reaktywowane ono zostało w roku 2000. Organizowane było przez 5 kolejnych lat, po czym do jego kolejnej reaktywacji doszło w 2009 roku. Dożynki są wydarzeniem oficjalnym, kreowanym odgórnie przez instytucje o charakterze państwowym, o słabej mocy integracyjnej na poziomie lokalnym i regionalnym. Traktowane są bardziej jako marka samej miejscowości niż jako obraz, którego treści związane są z mieszkańcami i ich doświadczeniami:

nie ukrywam, że jak gdzieś jedziemy na targi czy inne imprezy wystawiennicze, to Spała jest rozpoznawalna właśnie dzięki Dożynkom Prezydenckim. I tym sprzed wojny i tym teraz. (SKP2_14)

Jasielskie Dni Wina to z kolei wydarzenie nawiązujące do tradycji winiarskich, których w Jaśle nie było i które zostały niejako wykreowane (wymyślone) na potrzeby promocyjne miasta. $\mathrm{Z}$ udzielonych informacji wynika, że idea imprezy zrodziła się z inicjatywy oddolnej, żywiołowej; wypłynęła od osoby uznawanej za pioniera winiarskiego w województwie podkarpackim i następnie zyskała poparcie władz miasta, którym powierzono organizację wydarzenia. Podobny był kontekst powstania, 
organizowanych w Krośnie Karpackich Klimatów ${ }^{6}$. Również powstały one na bazie inicjatyw oddolnych ${ }^{7}$ i w dalszej kolejności zyskały akceptację i wsparcie organizacyjne oraz finansowe władz miejskich. W obecnym kształcie dominującą rolę $\mathrm{w}$ organizacji wydarzenia odgrywa miejska instytucja kultury Regionalne Centrum Kultur Pogranicza, która to określa kształt projektu kulturalnego, podejmuje decyzje merytoryczne oraz działania promocyjne. Sama koncepcja Karpackich Klimatów nawiązuje do wykreowanych tradycji winiarskich oraz do pogranicznego położenia i tradycji: „konwencja jest jedna, czyli promocja kultur pogranicza, promocja sztuki pogranicza i taki jest zamysł” (SKS5_14). Kolejne wymienione wydarzenie będące obrazem „narzuconym” to organizowana w Przemyślu pod patronatem Prezydenta Miasta Wincentiada (aneks, zdjęcie 1). Wincentiada to obchody dni patrona miasta Przemyśla św. Wincentego, którego relikwie znajdują się w miejscowym kościele o. Franciszkanów. Z uwagi na jarmarczny i festynowy charakter obchodów, wydarzenie ma charakter religijno-świecki. Jako święto religijne Wincentiada organizowana była od wieku siedemnastego aż do wybuchu II wojny światowej. Nowa formuła wydarzenia powstała $\mathrm{w}$ latach dziewięćdziesiątych, kiedy to powrócono do idei organizacji wydarzenia i zaczęto je kreować na nowo. Obecna koncepcja wydarzenia opiera się o szereg elementów, które ściśle związane są z lokalną historią i tradycją (zwłaszcza mieszczańską), a jego zasadniczym celem jest integracja mieszkańców:

Taka impreza w mieście jest potrzebna i myślę, że ona buduje identyfikację z miastem. To jest takim podstawowym zadaniem. (...) Ja myślę, właśnie święto, które kultywuje tradycję, buduje tą taką tożsamość miejską. (P1_13)

Co ciekawe w koncepcji wydarzenia rzadko akcentowany jest fakt wielokulturowości miasta. Skupia się raczej uwagę na tym co miejskie-lokalne; nie włączając w to tradycji wielokulturowości. Kontekst tworzenia obrazów „narzuconych” i jego treści jest zatem mocno zinstytucjonalizowany. Jest też bardzo scentralizowany, co widać zwłaszcza na przykładzie Dożynek Prezydenckich w Spale, gdzie wszelkie uprawnienia do podej-

6 Zarówno Karpackie Klimaty, jak i Dni Wina w Jaśle wpisane są w powstałą w roku 2006 ideę „Podkarpackiego Trójmiasta", która przez lokalne media określana jest jako wspólna marka, budowana zarówno w celach promocyjnych regionu, jak i jako rodzaj „instytucji” ułatwiającej pozyskanie funduszy strukturalnych i sprzyjającej rozwojowi gospodarczemu regionu. Przez samych badanych idea „Podkarpackiego Trójmiasta” nie jest określana jako marka, a części z nich nie jest nawet znana.

7 Wydarzenie zainicjowane zostało przez stowarzyszenie społeczno-kulturalne, skupiające ludzi-pasjonatów, działających na danym polu (tu znawców i miłośników wina). 
mowania decyzji organizacyjnych są przeniesione na struktury centralne (na Kancelarię Prezydenta RP) oraz na przykładzie przemyskiej Wincentiady, gdzie w proces kreacji zaangażowane są wiodące instytucje kultury i kościół katolicki, a całość projektu cechuje dość wysoki stopień centralizacji procesu decyzyjnego. Proces tworzenia obrazów „narzuconych” niejednokrotnie opiera się na z góry określonych schematach działań i specjalnie skonstruowanych strategiach. Jest też on bardzo przemyślany i uwzględnia potencjalny sposób recepcji. Z takimi sposobami działania mamy np. do czynienia w przypadku Dni Wina w Jaśle. Organizacja tego wydarzenia wpisana jest bowiem $\mathrm{w}$ strategię polityki kulturalnej miasta oraz $\mathrm{w}$ strategię wizerunkową "Jasło-winne klimaty”, która sformułowana została na podstawie odpowiednich badań i diagnozy opinii mieszkańców i turystów: „Z tych wszystkich przesłanek, wszystkich wypowiedzi, analiz, ankiet, wyszło że jednak najsilniej kojarzeni jesteśmy z winiarstwem ogólnie” (SKS6_14). W przypadku obrazów „narzuconych” mamy też do czynienia z częstszym czerpaniem z zewnętrznych inspiracji i wzorów. Przykładowo, dla przemyskiej Wincentiady najistotniejsze znaczenie zdaje się mieć partnerstwo Przemyśla z niemieckim miastem Paderborn, gdzie organizowane obchody dnia Liberiusza stały się głównym źródłem inspiracji do stworzenia analogicznego święta w Przemyślu. To co cechuje obrazy „narzucone” to także podejmowanie szeroko zakrojonych działań promocyjnych: wykorzystanie reklamy wewnętrznej: w ramach lokalnej społeczności oraz w regionie oraz wykorzystanie reklamy zewnętrznej, outdoorowej, zwykle o zasięgu ogólnopolskim.

\section{Obrazy „długiego trwania”}

Swoją nazwą obrazy „długiego trwania” nawiązują do braudelowskiej koncepcji „długiego trwania” (fr. longue durée) i tak jak ta kategoria akcentują rolę perspektywy czasowej. W ich treść wpisuje się to, co w danym mieście trwałe (utrwalone od długiego czasu), mające moc tożsamościową oraz integrującą. Są one niejako zakorzenione w historii miejsca, obecne w zbiorowej pamięci od dawna. Obrazy „długiego trwania” są bardziej wyraziste, bardziej jednoznaczne, a proces ich kreowania odbywa się głównie przy wykorzystaniu zasobów społeczno-kulturowych, zwłaszcza dziedzictwa kulturowego i lokalnej historii (często zmitologizowanej przeszłości). Wyraża się to m.in. w słowach: „my tu budujemy markę wokół tego co mamy" (SKS4_14). Kontekst czy też treść tych obrazów tworzy to, co wytwarzane być nie musi, co w danej miejscowości już jest, a zatem to co najbardziej lokalne, swojskie, specyficzne dla tej właśnie społeczności, 
z czym łatwo się utożsamić. Typowymi przykładami tego rodzaju marek będą: łowicki folklor, sanocki skansen i tzw. galicyjskość, przemyski Szwejk, fajka czy niedźwiadek oraz ikony w Sanoku. Przyjrzyjmy się niektórym z nich. Łowicki folklor (aneks, zdjęcie 2a), na który składają się m.in. stroje, wycinanki, hafty, wyrósł z tradycji ziemi łowickiej i bardzo silnie odwołuje się do historycznego regionu: Księstwa Łowickiego. Folklor łowicki jest dziedzictwem kulturowym Łowicza i ziemi łowickiej i jako taki jest rozpoznawalny nie tylko w Polsce, ale i poza jej granicami. Co więcej odgrywa on ważną rolę w określaniu tożsamości, jest bowiem elementem niejako naturalnym, obecnym w przestrzeni miasta od wielu pokoleń:

I budujemy... tą markę folklor niewątpliwie o ten regionalizm, który związany był z Księstwem Łowickim. On powstał tam w XVII wieku; My mamy najsilniejszy folklor tutaj i my to zawsze musimy mieć. I to jest... to jest już wpisane prawie w program każdego naszego takiego większego wydarzenia. (ŁS2)

Silny nacisk na regionalizm i specyficzną, wyjątkową historię miejsca występuje też w przypadku sanockiego skansenu i tzw. galicyjskości. Sanocki skansen, czyli Muzeum Budownictwa Ludowego posiada unikatowe zbiory nawiązujące do dziedzictwa regionu i jest on definiowany przez badanych jako szczególna wartość Sanoka, rozpoznawalna na całym świecie. Taką wartością szczególną jest również tzw. „galicyjskość”, nawiązująca do wielokulturowej historii regionu, pogranicznego położenia, do zmitologizowanej już dziś krainy, jaką była dawna Galicja. W samym mieście organizowane są liczne imprezy desygnowane przymiotnikiem "galicyjskie”. I tak: odbywają się Noce Kultury Galicyjskiej; w sanockim skansenie działa rynek miasteczka galicyjskiego, na którym co miesiąc odbywa się targ staroci „Galicyjska Graciarnia”; w mieście funkcjonuje też restauracja „Galicja”, a lokalna stacja telewizyjna nosi nazwę „TV Galicja”: Galicyjskość jest również przywoływana w odniesieniu do klimatu miasta i postaw jego mieszkańców:

Tu jest wszystko powolne, ospałe, galicyjskie; Galicyjskość jest takim chwytliwym. Galicja jest takim elementem spajającym te tereny. Ludzie mają tak, że nie wiedzą czym jest ta galicyjskość, ale każdemu się wydaje.... (SKA4_14)

Na obrazy „długiego trwania” składają się zatem głównie elementy przeszłości, zwłaszcza tej zmitologizowanej. Tak też jest w przypadku przemyskiego niedźwiadka i Szwejka. Treść pierwszego obrazu stanowi wizerunek niedźwiedzia brunatnego. Jako element herbu oraz flagi jest on symbolem miasta. Symbol ten nawiązuje do legendarnych początków miasta (jego 
tysiącletniej historii) oraz do uzyskania w wieku czternastym przywileju lokacyjnego na prawie magdeburskim (pod sylwetką niedźwiadka widnieje napis Libera Regia Civitas, co oznacza Wolne Królewskie Miasto). Sylwetka niedźwiadka na stałe wpisana jest też w ikonosferę miasta, gdyż jako element architektoniczny - fontanna, umiejscowiona jest w centralnym punkcie miasta - na Starym Rynku. Co więcej w mieście działa też Klub „Niedźwiadek”, a jedna z lokalnych drużyn sportowych nosi nazwę „Przemyskie Niedźwiadki”. Podobnie mocno utrwalonym obrazem, zarówno w świadomości jak i jako obiekt materialny, jest przemyska postać Szwejka. Bohater powieści Jaroslava Haska stanowi element małej architektury - jest pomnikiem-ławeczką (aneks, zdjęcie 2b), zlokalizowaną na Starym Rynku w Przemyślu i jako taki stanowi swoistą wizytówkę miasta. Sama postać Szwejka jest zaś bardzo kultywowana m.in. poprzez działalność „Szwejków”, czyli powołanego przez Leszka Mazana Stowarzyszenia Miłośników Dobrego Wojaka Szwejka oraz organizację co rocznych Manewrów Szwejkowskich, na które zjeżdżają się nie tylko miłośnicy bohatera powieści J. Haska z całej Polski, ale i z Czech i Słowacji:

Szwejki również, bo ktokolwiek nie przyjedzie, wycieczki fotografują się ze Szwejkiem; Mi najbardziej utkwił w pamięci Szwejk i (...)i ci panowie i panie z tego Stowarzyszenia Dobrego Wojaka Szwejka kreują bardzo pozytywnie Przemyśl, bo robią te manewry szwejkowskie, wszystko jest w żartobliwym tonie, na bardzo fajnym poziomie. (P3_13)

Sama postać Szwejka także nawiązuje do lokalnej historii i tradycji, a zwłaszcza do swego rodzaju kultywowania (choć nie tak wyraźnie jak to ma miejsce w przypadku Sanoka) świetności dawnej Galicji:

najbardziej popularną jest tradycja Austrii, zaborów i Twierdzy Przemyśl. To jest taka najbardziej istniejąca w świadomości. (P1_13)

Cechą charakterystyczną obrazów „długiego trwania” jest to, że ich upowszechnianie jest częściej niż w przypadku obrazów „narzuconych” inicjatywą oddolną, a głównym sposobem społecznego tworzenia obrazu jest opisany model partycypacyjny/inkluzyjny. Widać to zwłaszcza w przypadku Przemyśla, gdzie bardzo pozytywnie odbierana jest działalność Stowarzyszenia "Szwejków”, z inicjatywy którego nie tylko ufundowano pomnik bohatera powieści i które jest głównym organizatorem wspomnianych Manewrów Szwejkowskich, ale którego członkowie z własnej woli i nieodpłatnie uświetniają swoją obecnością każdą ważniejszą imprezę plenerową w mieście. Opierając się na modelu partycypacyjnym kreowane są również 
takie marki, jak sanocki skansen. Strategia podejmowanych tutaj działań zawiera: silne działania promocyjne, wykorzystanie dziedzictwa wielokulturowości, swego rodzaju zgodność definicji marki, spójność podejmowanych działań; a także gotowość, do uwzględniania inicjatyw oddolnych. Akt kreacji obrazów „długiego trwania” opiera się zatem głównie na czerpaniu z zasobów wewnętrznych, a głównymi aspektami podejmowanych działań są: znaczenie postaci/podmiotu w społeczności lokalnej, znaczenie postaci/ podmiotu w środowisku zewnętrznym, w tym na arenie międzynarodowej, a także odwołanie do kulturowych tradycji miasta.

\section{Obrazy „na sprzedaz”}

Obrazy „na sprzedaż” wiążą się z wąskim sposobem pojmowania marki lokalnej jako konkretnych produktów i towarów oferowanych przez lokalnych producentów. Są to produkty wytwarzane w danym miejscu, w oparciu o zasoby regionu. W tym przypadku możemy mówić o produkcie markowym (spożywczym, ludowym, turystycznym i innych), który identyfikowany jest $\mathrm{z}$ określonym miejscem/miejscowością. Produkty te promują miasto, region, współtworzą jego ofertę turystyczną, kulturową, komercyjną, inwestycyjną. Ich przykładami będą znane na rynku krajowym i zagranicznym „wyroby lokalne” takie, jak: produkty mleczarskie i dżemy w Łowiczu, kosmetyki Inglot w Przemyślu, Centralny Ośrodek Sportu w Spale, fabryka Autosan w Sanoku oraz szkło krośnieńskie. Te lokalne produkty - identyfikowane i utożsamiane są z danym miastem, regionem, promują go, wpływają na jego rozpoznawalność. Marka jako obraz „na sprzedaż” konceptualizowana jest przede wszystkim w kategoriach ekonomicznych. Jest ona przedmiotem umowy kupna-sprzedaży, a to pozwala nam na interpretowanie jej w kategorii procesu „utowarowienia obrazu”. Na ten aspekt funkcjonowania obrazów, zwracał uwagę m.in. P. Sztompka, pisząc o „logice ekonomicznej skupionego na konsumpcji kapitalizmu" [Sztompka 2012: 14]. Żyjemy w społeczeństwie konsumpcyjnym, gdzie komercjalizacja dotyczy wszystkich dziedzin życia, gdzie, jak się powiada „wszystko jest na sprzedaż”, a sam dostęp do towarów, różnych atrybutów statusu, demokratyzuje się [Sztompka 2012: 18]. Dzisiaj, pisze P. Sztompka, istotny jest brand, marka, i to, czy jest autentyczna, a nie podrobiona w Chinach, choć to już rozpoznać niełatwo [Sztompka 2012: 18]. Konkurencyjność dzisiejszego rynku wymaga oryginalności, atrakcyjności, innowacyjności produktu. Strategia pozyskiwania uznania innych, wynikająca z samej logiki konsumpcyjnego rynku, została zastosowana m.in. w przypadku badanych miejscowości. 
W Przemyślu przykładem marki-obrazu „na sprzedaż” jest firma Inglot. Stworzone przez przemyślanina Wojciecha Inglota przedsiębiorstwo jest obecnie rozpoznawalne na rynku krajowym oraz zagranicznym. Sam przedsiębiorca zaangażowany był w życie kulturalne miasta, wspierał finansowo wiele podejmowanych inicjatyw lokalnych. Generalnie panuje tu zgoda co do tego, że Inglot jest marką Przemyśla:

Na pewno Inglot jest to firma, która jest... która zrobiła oszałamiającą karierę nie tylko w Polsce ale i za granicą. Przedwczesna śmierć Wojtka Inglota była tutaj dla wszystkich ciosem. Sądzę, że Wojtek Inglot i jego firma mogła być tutaj taką lokomotywą, która pociągnie to miasto nie tylko od strony biznesowej czy takiej właśnie, takiego brandu, prawda? (P6_13)

Kolejnym przykładem marki-obrazu „na sprzedaż” jest Centralny Ośrodek Sportu w Spale. Jest to miejsce, w którym odbywają się treningi kadry narodowej i olimpijskiej w kilkudziesięciu dyscyplinach sportowych, jak również miejsce odpoczynku dla osób spoza świata sportu. Oferując usługi z zakresu rehabilitacji i odnowy biologicznej COS promuje Spałę na rynku krajowym:

Czyli Spała już mając swoją nazwę po prostu tą markę coraz bardziej jeszcze szlifuje. (...) To że tu się dzieją od paru lat te jarmarki, i że przywrócono dożynki prezydenckie, i że jest ten Hubertus, i że są znowu te ośrodki, i że jest Centralny Ośrodek Sportu, to sprawia, że ta miejscowość znaczy na mapie Polski. (S7_13)

W analogiczny sposób opisać można Sanocką Fabrykę Autobusów „Autosan”, dzięki której Sanok stał się istotnym ośrodkiem przemysłowym (szczególnie w latach 1950-1990) oraz Krośnieńską Hutę Szkła, w przypadku której mamy do czynienia z wyrazistą marką Krosna jako „miasta szkła”, rozpoznawalnego nie tylko w Polsce, ale i za granicą:

Wie Pani, no Sanok od zawsze był kojarzony z dwoma rzeczami: z fabryką autobusów i Skansenem, tak to można powiedzieć; Autosan (...) wielka, wielka taka fabryka autobusów, które od lat były znane w całym świecie. (SKA4_14)

Wyróżniając typologię marek-obrazów zwróciliśmy uwagę na fakt, że kategorie „długiego trwania” czy „narzucone” mogą pełnić również rolę marek-obrazów „na sprzedaż”. Przykładem jest m.in. opisany wcześniej Folklor Łowicki:

jednocześnie na tym folklorze nasi twórcy ludowi zarabiają pieniądze. Realizujemy dwa projekty unijne, oba powyżej $1 \mathrm{mln}$ złotych dofinansowania zewnętrznego 
i te warsztaty ludowe, które organizujemy, to są z odpłatnością dla twórców, więc można po prostu na tej twórczości zarobić. (...) Wycinaneczki, wycinaneczki, ale coś trzeba z tego mieć. (ŁS1)

Jest to przykład czerpania z zasobów nie tylko lokalnych (np. społeczno-kulturowych), ale również ponadlokalnych (np. potencjału strukturalnego wynikającego z akcesji do struktur unijnych). Głównym celem łowickiego wydarzenia Księżackie Jadło jest promocja Łowicza przy wykorzystaniu kuchni regionalnej (lokalnej żywności i potraw):

Myślę, że Łowicz jest znany z tych dużych, łowickich firm. Jednak, jak w telewizji pojawiają się mleczarnie łowickie, czy dżemy łowickie, to gdzie się nie pojawiam i przedstawiam się, że jestem z Łowicza, to każdy: „a, tam te dżemy”, „a, tam to mleko". To też jest ważne, że lokalne nasze duże firmy, przedsiębiorcy tak prężnie działają, że ich po prostu stać na taką dużą reklamę. Zatem, chodzi o to, by twórcy zarabiali pieniądze, Łowicz odwiedziła jak największa liczba osób, oraz by umilić ludziom czas wolny, bo im też należy się rozrywka. (ŁA1)

Marka-obraz „na sprzedaż” wymaga nie tylko zidentyfikowania jej w kategorii „marki” czy zaistnienia w szerszej świadomości, ale również obejmuje proces jej komercjalizacji i czerpania zysków. Na podstawie powyższych przykładów marek-obrazów „na sprzedaż” daje się zauważyć, iż marka nie powstaje dla samego prestiżu posiadania elementu różnicującego, ale powinna przynosić wymierne korzyści. Marka jako produkt

ma się sprzedawać: Jeżeli to jest rozpoznawalne i się sprzedaje, to jest marką. No bo przecież to Jadło może być marką. Jeżeli by było i tyle ludzi ściągało, możemy i co miesiąc robić. (...) Kto powinien na tym zarabiać? Pani ma w Łowiczu bar, restaurację. Ja mam. I sprzedajemy powiedzmy te kluski rwoki. My płacimy podatek, miasto na tym zarabia. ((ŁA5)

Marka-obraz „na sprzedaż nie tylko promuje miasto czy region. Silna marka wspiera także promocję lokalnych instytucji, innych produktów, symboli czy wydarzeń organizowanych w społeczności lokalnej. Marka-obraz „na sprzedaż” jest tu przyczynkiem rozpoznawalności, przyciągania potencjalnych mieszkańców, turystów, ale również inwestorów. Jest wsparciem dla rozwoju, innowacji, podniesienia konkurencyjności i pozycji rynkowej lokalnych podmiotów. 
Obrazy typu brand mind map

Obrazy typu brand mind map ${ }^{8}$ można konceptualizować jako sieć pojęć w umysłach innych; jako swoiste pojęcia-puzzle, które wzięte razem tworzą lub mogą tworzyć całość czyli obraz miasta, regionu, kraju.

$\mathrm{Na}$ podstawie analizy badań ${ }^{9}$ przeprowadzonych wśród uczestników odświętnych wydarzeń w Przemyślu, Sanoku, Spale i Łowiczu można naszkicować przykładowe mapy wydarzeń, miejsc, postaci, symboli, które jako suma elementów zapewniają lub mają tendencję do zapewnienia jednolitego obrazu miasta.

Tworzenie marki/marek związanych z Przemyślem odbywa się przy wykorzystywaniu zasobów lokalnych, przede wszystkim społeczno-kulturowych, ludzkich, strukturalnych, a także w oparciu o zewnętrzne inspiracje. Wybory miejsc, symboli i produktów tworzących markę miasta dokonywane przez podmioty profesjonalne $\mathrm{i}$ „społeczne” $\mathrm{w}$ znacznym stopniu pokrywają się z wyborami dokonywanymi przez odbiorców ich działań. Różnice dotyczyły jedynie elementów krajobrazu architektonicznego miasta (Stary Rynek, zabytki sakralne), które częściej wskazywane były przez uczestników Wincentiady, oraz Teatru Amatorskiego „Fredreum”, który wymieniany był głównie przez aktorów profesjonalnych i „społecznych”. Zatem, na obraz Przemyśla składają się: znajdujący się w herbie miasta Niedźwiadek (symbol miasta); Szwejk (postać); Manewry Szwejkowskie (wydarzenie); fajka i firma Inglot (produkt), oraz Forty będące elementem historycznym i architektonicznym:

8 Określenie marki-obrazu typu brand mind map zrodziło się ad hoc, jako inspiracja posłużyło tu nawiązanie do techniki mapowania myśli [Buzan 2004], która jest wykorzystywana w różnego rodzaju szkoleniach, m.in. z nauki szybkiego zapamiętywania, czy budowania strategii marketingowych.

9 Zwrócić należy uwagę na różnice pomiędzy technikami, jakie były zastosowane $\mathrm{w}$ analizowaniu dwóch perspektyw postrzegania marki lokalnej: przez mieszkańców i animatorów kultury. Ankieta skierowana do mieszkańców w pewien sposób porządkowała kategorię marki miasta, skupiając się na treściach, jakie mogą ją wypełnić i jednocześnie przez wiele podpowiedzi (że może to być postać, przedmiot, miejsce lub wydarzenie - w sumie siedem możliwości) sugerowała szerokie rozumienie marki, obecne np. we współczesnym marketingu terytorialnym. W przypadku animatorów, pytania o markę lokalną były otwarte. Umożliwiło to rekonstrukcję indywidualnych sposobów definiowania marki przez animatorów. 
Rysunek 1. Obraz miasta Przemyśl według uczestników Wincentiady

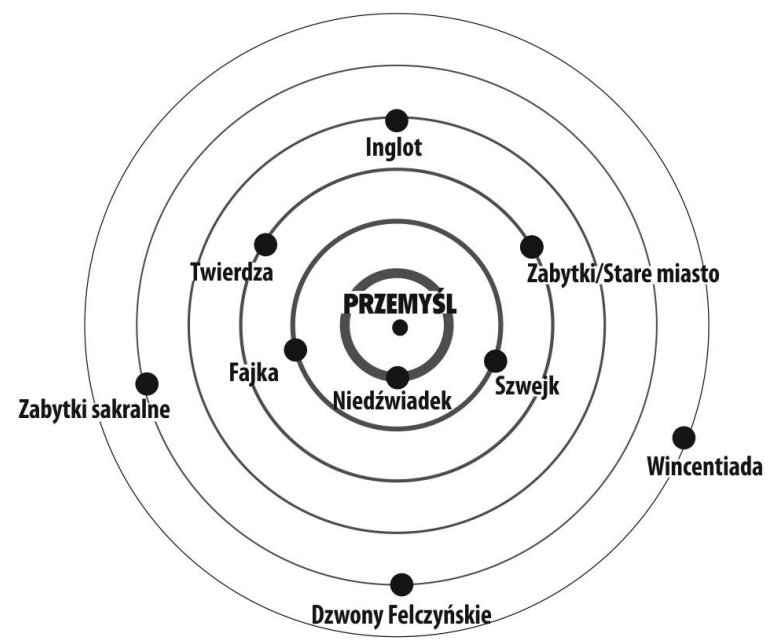

Wyjaśnienie do map: grubość kręgów oznacza liczbę głosów oddanych na wydarzenie, postać, symbol, inny element wskazany przez uczestników obserwowanych wydarzeń jako marka: im grubsza linia, tym więcej głosów dany element uzyskał.

Legenda: Na podstawie wyników ankiet przeprowadzonych wśród uczestników Wincentiady (86 ankiet): Niedźwiadek uzyskał 22 wskazania, Szwejk (zarówno postać, jak i wydarzenie Manewry Szwejkowskie) uzyskały 12 wskazań, następnie Fajka (jako produkt i wydarzenie) - 12, Zabytki/Stare miasto - 9, Twierdza - 8, Inglot - 5, Zabytki sakralne - 4, Dzwony Felczyńskie -4 , Wincentiada -2 .

Kolejne uwzględnione $\mathrm{w}$ badaniu miasto - Spała - w budowaniu marki/marek czerpie przede wszystkim z zasobów kulturowych i instytucjonalnych. Elementami składowymi tego obrazu są tu głównie: Centralny Ośrodek Sportu, żubr, Hubertus Spalski i spalske jarmarki, dopiero w dalszej kolejności Dożynki Prezydenckie, kościół, ośrodek wczasowy oraz postać Ignacego Mościckiego:

Bardziej pogłębiona analiza wykazała, że w przypadku Spały istnieje pewna rozbieżność pomiędzy wyobrażeniem o marce Spały wśród jej mieszkańców a twórcami/organizatorami odświętnej rzeczywistości miejscowości. Spalscy aktorzy profesjonalni mówią o Dożynkach jako o marce miejsca, o jarmarkach i ośrodku sportowym, o próbie „zbudowania jednej marki pod hasłem «Spała»", która pozostaje nieczytelna dla bezpośrednich odbiorców, czyli społeczności lokalnej. 


\section{Rysunek 2. Obraz miasta Spała według uczestników Dożynek Prezydenckich}

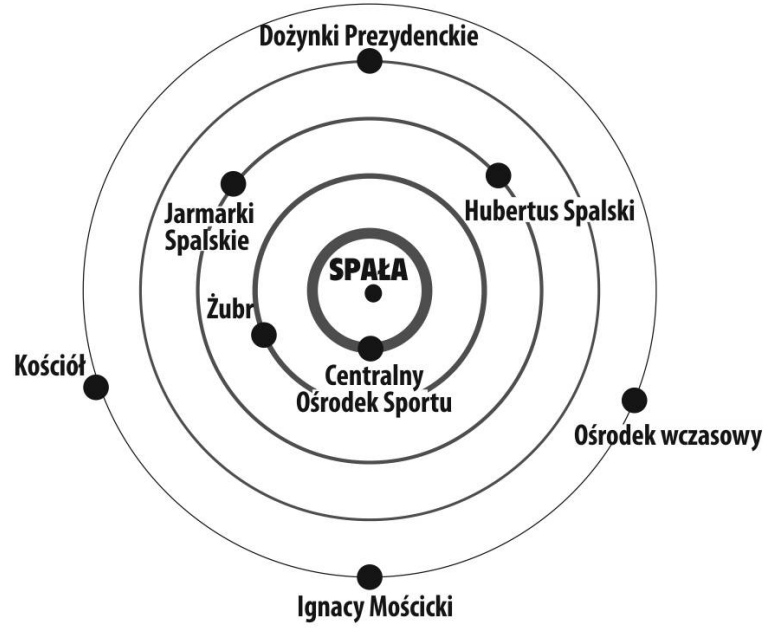

Legenda: Na podstawie wyników ankiet przeprowadzonych wśród uczestników Dożynek Prezydenckich (50 ankiet). Największą liczbę wskazań wśród uczestników ankiety uzyskał Centralny Ośrodek Sportu - 18 głosów, na drugim miejscu znalazł się Żubr - 10 głosów, na trzecim - Hubertus Spalski i Jarmarki Spalskie ze wskaźnikiem po 6 głosów, Dożynki Prezydenckie uzyskały 4 wskazania.

\section{Rysunek 3. Obraz miasta Sanok według uczestników Jarmarku Sanockiego}

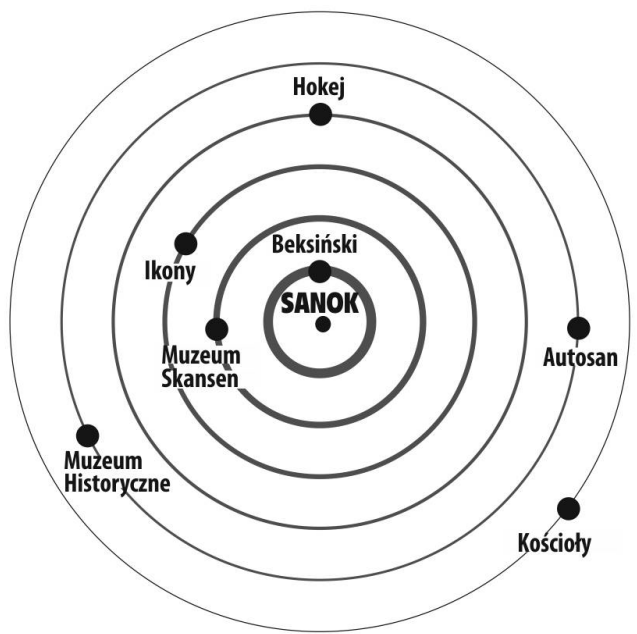

Legenda: Na podstawie wyników ankiet przeprowadzonych wśród uczestników Jarmarku Sanockiego (80 ankiet). Najwięcej wskazań uzyskał Beksiński - 19 i Muzeum Budownictwa Ludowego - 17, na kolejnych pozycjach znalazły się Ikony - 9, Hokej - 6, Muzeum Historyczne, Rynek Galicyjski i Autosan uzyskały po 4 wskazania. 
Problemów z rozpoznaniem tego, jakie treści można powiązać z marką miasta nie ma w przypadku Sanoka. W mieście tym kreowanie marki odbywa się przy wykorzystaniu głównie zasobów lokalnych. Najczęściej wskazywany tu był Zbigniew Beksiński (postać); Muzeum Budownictwa Ludowego, Skansen (instytucja); ikony (symbol/przedmiot), drużyna hokejowa czy ogólnie hokej:

Łowicz również jest przykładem wykorzystywania czynników głównie wewnętrznych (lokalnych) w kreowaniu marki. Aktorzy profesjonalni i „społeczni” szczególną uwagę zwracali na folklor jako najbardziej rozpoznawalny na zewnątrz element kultury łowickiej. Jakkolwiek wybór folkloru wydawał się najbardziej oczywisty, wymieniane były również inne elementy, jak dżemy i mleko łowickie jako produkty, Boże Ciało jako wydarzenie, sporadycznie pojawiały się w kontekście marki lokalnej postaci związane z historią i kultura Łowicza:

Rysunek 4. Obraz miasta Łowicz według uczestników Księżackiego Jadła

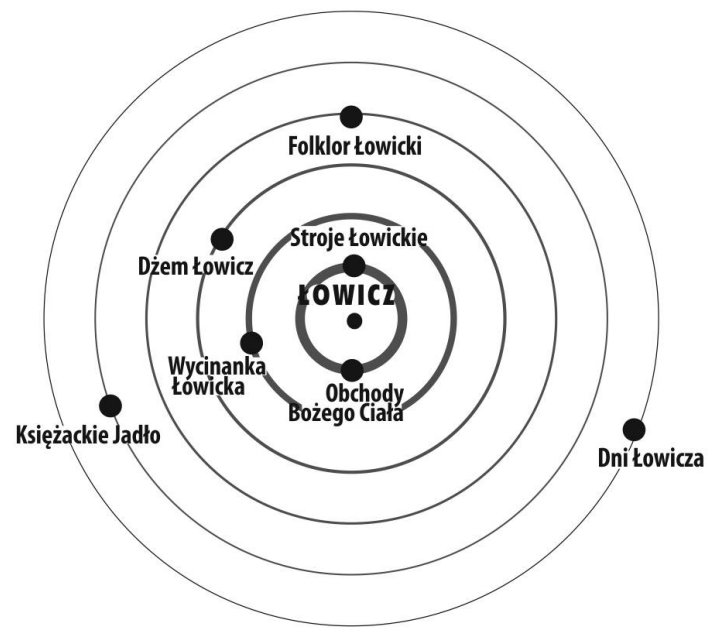

Legenda: Na podstawie wyników ankiet przeprowadzonych wśród uczestników Księżackiego Jadła (40 ankiet). Boże Ciało i stroje łowickie uzyskały najwięcej - po 12 wskazań, następnie została wymieniona wycinanka łowicka -8 wskazań, dżem Łowicz - 6 wskazań, folklor -5 , Księżackie Jadło - 4, produkty mleczne - 4, Dni Łowicza - 3 .

Niezależnie od modelu działania podmiotów profesjonalnych, jak i „społecznych”, mieszkańcy badanych miejscowości włączani są w analizowane tu imprezy głównie w charakterze biernego odbiorcy, dlatego obraz brand mind map pozwala na ukazanie tego, czy istnieje zgodność pomiędzy strategiami budowania marki przez twórców, a ich czytelnością wśród 
odbiorców. W przypadku Przemyśla, Sanoka i Łowicza widać pewną zgodność co do marki/marek miast. Wyjątek stanowi tu Spała, gdzie przykład analizowanego wydarzenia o charakterze narodowo-państwowym (Dożynki Prezydenckie) ukazał słabą integrację na poziomie lokalnym - ograniczoną komunikację podmiotów profesjonalnych z bezpośrednimi odbiorcami ich działań, czyli społecznością lokalną. Podmioty kultury z Przemyśla, Sanoka i Łowicza w myśleniu i działaniu na rzecz marki lokalnej, regionalnej czy narodowej łączą z różną intensywnością rolę "prawodawcy” i „tłumacza” (wykorzystując pojęcia Z. Baumana [1997]) społeczności lokalnej, a animatorom Spały bliżej do roli kompetentnych w sprawach kultury lokalnej „tłumaczy” odgórnych koncepcji święta niż autonomicznych „prawodawców” i „tłumaczy” interesów i oczekiwań lokalnej społeczności. Natomiast społeczność lokalna musi się identyfikować $\mathrm{z}$ marką, ponieważ $\mathrm{w}$ ten sposób staje się jej naturalnym i autentycznym propagatorem na zewnątrz. Społeczność lokalna jest zatem niezbędna w procesie identyfikacji marki lokalnej, regionalnej, narodowej.

Marka-obraz typu brand mind map uwidocznia swoisty pluralizm marki. W badanych miejscowościach istnieje wiele elementów o charakterze markowym, lecz powiązanie między nimi jest słabe. Oznacza to, że nie składają się one na spójny obraz miasta i to pomimo prób jego ujednolicenia, czego najlepszym przykładem jest próba tworzenia spójnej ikonosfery w Sanoku pod hasłem „SanOk” czy wykorzystywanie elementów folkloru w Łowiczu.

\section{Podsumowanie}

Analiza marki, a w zasadzie procesów markotwórczych, angażuje nas w dwa zasadnicze procesy: konstruowania rzeczywistości oraz jej oceniania. Konstruowanie rzeczywistości za Jeffreyem Alexandrem można rozumieć w kategoriach strukturalnych i semiotycznych. Obejmuje ono nazywanie, nawiązywanie i przeprowadzanie analogii, a każde z nich bazuje na typizacji i inwencji aktorów społecznych [Alexander 2010: 38]. Każdy obiekt lub to, co może posłużyć jako marka jest symbolizowany. Nazwy, odpowiedniki, analogie tworząc rzeczywistość symboliczną są również rozmaicie oceniane, są emocjonalnymi i duchowymi mapami poruszania się w otaczającej nas rzeczywistości, zarówno tej odświętnej, jak i codziennej.

Proces budowy marki stanowi swoiste "uproszczenie" wielu informacji związanych z danym miejscem, produktem, symbolem, postacią, wydarzeniem. Tworzy obraz, który jest kategorią poznawczą (tzn. obejmuje 
wiedzę na temat marki lub tego, co nią może być), ale i wysoce subiektywną. Marka jako obraz stanowi zatem „przefiltrowaną, mentalną reprezentację rzeczywistości” [Szromnik 2012: 146], gdzie funkcje filtrów spełniają cechy i charakterystyki osobowości odpowiednich jednostek, sposoby patrzenia i wartościowania rzeczywistości, postawy i zachowania społeczne, a także pozostaje pod wpływem otoczenia i czynników zewnętrznych (polityki kulturalnej, działań promocyjnych).

Zatem, proces budowania marki, jej konstruowania przez różne podmioty (aktorów profesjonalnych, jak i społecznych) jest jakby obrazem "pożądanym” (takim, jakim widzą go twórcy marki), a obraz „odbierany” jest konsekwencją procesów, które składają się na konstrukt marki, jest jej efektem, czyli obrazem wewnętrznym, tym w „ludzkiej głowie”. Między tworzeniem a odbiorem marki może istnieć pewien rozdźwięk. Dzieje się tak dlatego, że odbiór marki jest „przefiltrowywany” przez konstrukty myślowe odbiorców (ich emocje, przeżycia, postrzegania rzeczywistości), to znaczy że obraz marki jest korygowany przez wiele wspomnianych wyżej czynników. Marka-obraz najpierw pojawia się w świadomości podmiotów działających, którzy podejmują działania w zakresie kreowania i propagowania marki, a następnie zostaje poddana odbioru. Kluczowe wydaje się tu być wyobrażenie aktorów profesjonalnych, jak i społecznych, że razem współtworzą markę (przy jednoczesnym uznaniu nadrzędności aktorów profesjonalnych). 


\section{Aneks}

Wykres 1. Podmioty kreujące marki Przemyśla i Spały według respondentów
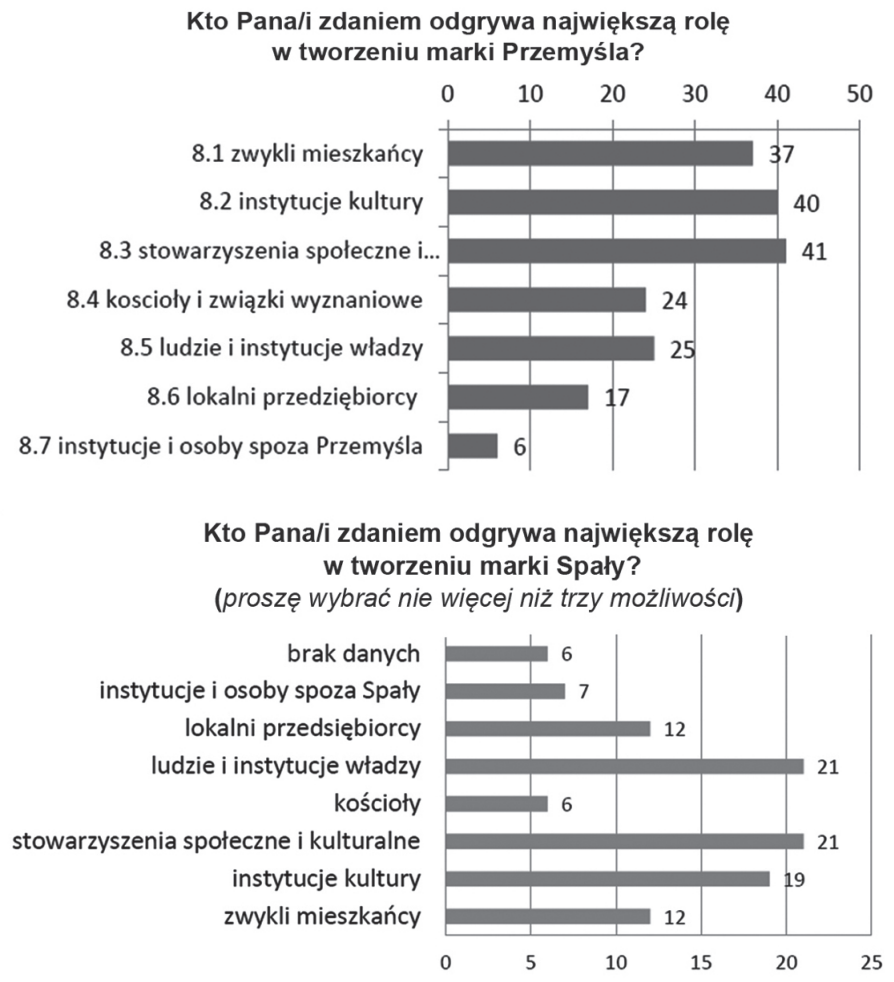

Główne podmioty kreujące marki-obrazy na przykładzie Przemyśla i Spały

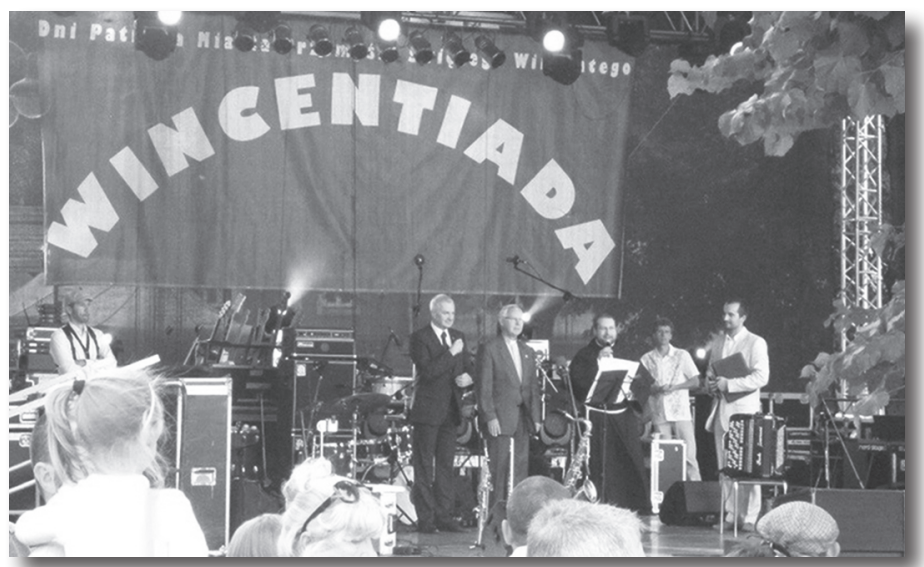

Zdjęcie 1. Obrazy „narzucone” - Dni Patrona miasta Przemyśl św. Wincentego 


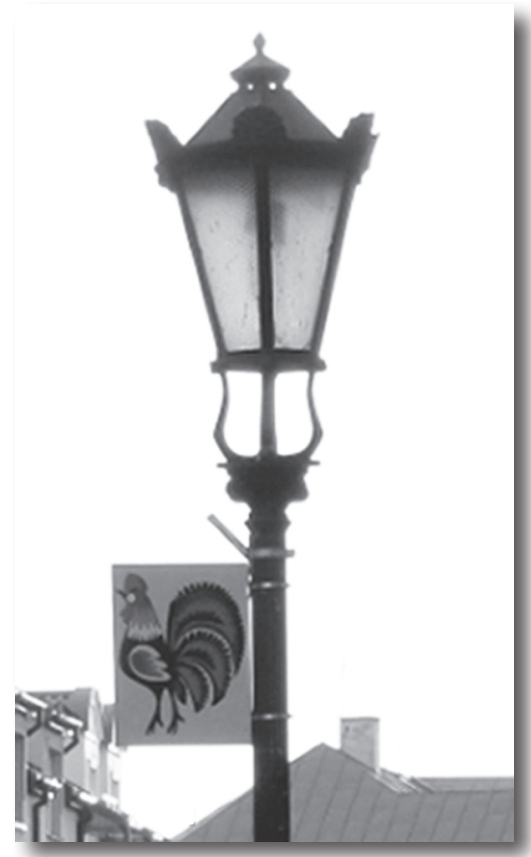

Zdjęcie 2a. Obraz „długiego trwania” - łowicki folklor

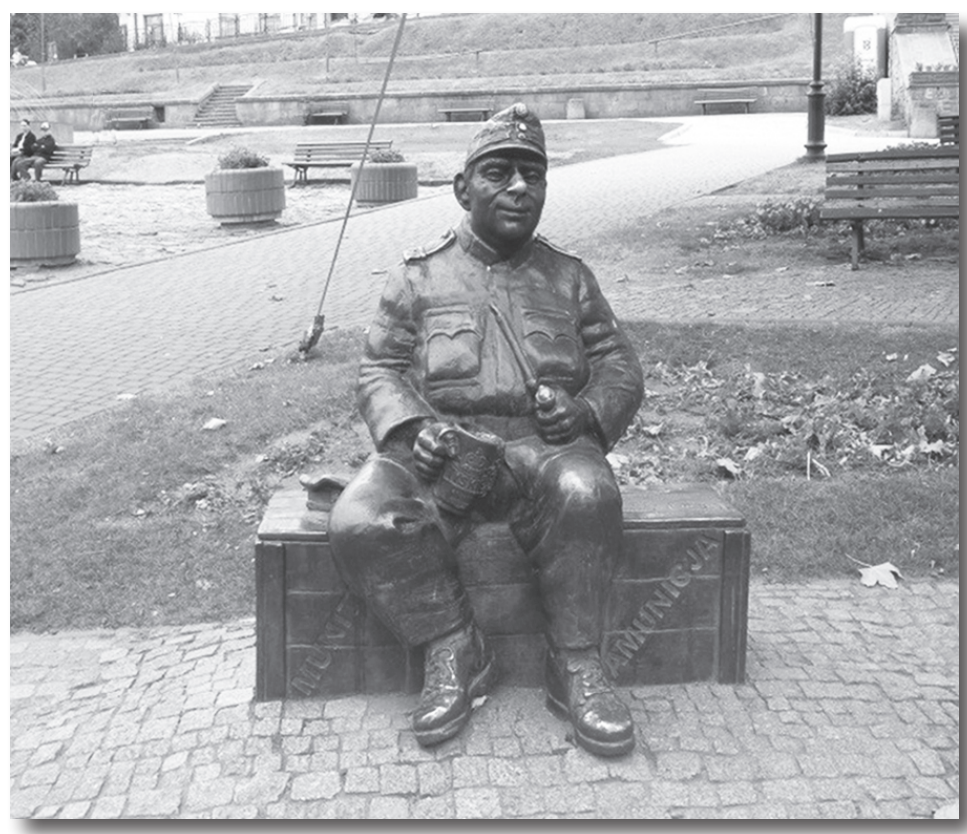

Zdjęcie 2b. Obraz „długiego trwania” - przemyski Szwejk 


\section{Bibliografia}

Alexander J. (2010), Znaczenia społeczne. Studia z socjologii kulturowej, Kraków.

Bauman Z. (1997), Prawodawcy i ttumacze, Warszawa.

Belting H. (2012), Antropologia obrazu, Szkice do nauki o obrazie, Kraków.

Berger P. L., Luckamann T. (2010), Społeczne tworzenie rzeczywistości, Warszawa.

Buzan T. (2004), Mapy Twoich myśli, Łódź.

Gostkowski Z. (1959), Teoria stereotypu i poglądy na opinię społeczna Waltera Lippmanna, „Archiwum Historii Filozofii i Myśli Społecznej”, nr 5.

Heidegger M. (1993), Czas światoobrazu, [w:] J. Bochemla, A. Kisielewska, M. Pęczak (red.), Wiedza o kulturze. Audiowizualność w kulturze. Zagadnienia i wybór tekstów, Warszawa.

Kubiak H. (1993), Stereotypy etniczne a komunikacja międzynarodowa, „Przegląd Polonijny", nr 4.

Lippman W. (1998), Public Opinion, New Brunshwick.

Manterys A. (1997), Wielość rzeczywistości w teoriach socjologicznych, Warszawa.

Mirzoeff N. (2012), Czym jest kultura wizualna, [w:] M. Bogunia-Borowska, P. Sztompka (red.), Fotospołeczeństwo. Antologia tekstów z socjologii wizualnej, Kraków.

Olechnicki K. (2003), Antropologia obrazu. Fotografia jako metoda, przedmiot i medium nauk społecznych, Warszawa.

Rose G. (2010), Interpretacja materiałów wizualnych. Krytyczna metodologia badań nad wizualnością, Warszawa.

Rzepińska M. (1988), W kręgu malarstwa, Warszawa.

Słownik Języka Polskiego, http://sjp.pwn.pl/sjp/obraz;2491859.html, [15.04.2016].

Szromnik A. (2012), Marketing terytorialny. Miasto i region na rynku, Warszawa.

Sztompka P. (2012), Socjologia wizualna. Fotografia jako metoda badawcza, Warszawa, PWN.

Sztompka P. (2012), Wyobraźnia wizualna i socjologia, [w:] M. Boguna-Borowska, P. Sztompka (red.), Fotospołeczeństwo. Antologia tekstów z socjologii wizualnej, Kraków.

Wendland M. (2011), Konstuktywizm komunikacyjny, Poznań. 


\section{SUMMARY}

\section{Brand as an image}

The presented article attempts to describe the local, regional and national brand in the terms of an image. The analysis is based on the assumption that an images are a significant interpretative framework of defining national and local brand. Reffering to the Walter Lippman's concept of a "pictures in our heads" we try to drift away from the tradition of thinking about a local and national brand and open new way of its interpretation. The applied approach allows to define local/national brand as a) a mental image, something imagined, allegorical image of a city, country, product, which is created by the people (a social actors), which is shared, identified and longstanding and as b) a construct having a material strand. Based on gathered empirical materials the Authors describes the process of social creation of a local and national brand as well as distinguishes fou $r$ main types of local brands/images: imposed images, long duration images, images for selling and brand mind map images.

KEYWORDS: image, local, reginal and national brand, Walter Lippman, constructionism, social creation of local brands 